\title{
An Assessment of the Growth of Ile-Ife, Osun State Nigeria, Using Multi-Temporal Imageries
}

\author{
O. A. Ajala ${ }^{1} \&$ A. M. Olayiwola ${ }^{1}$ \\ ${ }^{1}$ Department of Geography, Obafemi Awolowo University, Ile-Ife, Nigeria \\ Correspondence: O. A. Ajala, Department of Geography, Obafemi Awolowo University, Ile-Ife, Nigeria. E-mail: \\ oajala@oauife.edu.ng, ajalacho@yahoo.com
}

Received: January 19, 2013 Accepted: March 20, 2013 Online Published: April 18, 2013

doi:10.5539/jgg.v5n2p43 URL: http://dx.doi.org/10.5539/jgg.v5n2p43

\begin{abstract}
This paper examined the use of GIS and Remote Sensing in monitoring the growth and development pattern of Ile-Ife, Osun State, Nigeria over a period of 21 years with a view to predicting its direction of growth. In effect, the study sought to identify and explain the rate and extent of changes in the study area between 1986 and 2007; measure the rate of urban growth in the study area between 1986 and 2007; assess the impact of urban growth on land use patterns; and predict the trend of urban growth in the study area.

Data for the study were generated from both primary and secondary sources. Remote Sensing Imagery of Landsat TM 1986, Landsat ETM 2002 and ALOS 2007 were used to measure the extent of growth and to show the effects of this growth on other Land use/Land cover types. Multi-temporal approach was adopted for the study to detect the changes in the imageries. Pixel analysis was employed to identify and compare the type, nature, trend and magnitude of change that occurred in the study area within the slated dates. The observed land use/land cover and population were projected to the next 15 years.

The results showed the growth of Ile-Ife and its effects on other land use classes. Pixel analysis revealed that changes occurred in the magnitude and rate of urbanization in the study area between 1986 and 2007. The results were discussed mainly focusing on the trend of urban growth expansion and its effect to the Environment natural resources, farmland and food security and its contribution to climate change. Its implications to urban planning were also discussed and the recommendations made.
\end{abstract}

Keywords: urban growth, Ile-Ife, multi-temporal satellite imageries

\section{Introduction}

The study of urbanisation has invoked the interest of experts from a wide range disciplines such as ecology, urban planning, civil engineering, sociology, administration and humanities, and the common man, as well. This is because of the multitude of activities and processes that take place in the urban ecosystems. The rapid and random expansion of urban centres along their peripheries is a typical phenomenon of urban landscape in developing countries. This uncontrolled growth is a very crucial issue stressing town planners because of the escalating problems of urban congestion, poor housing, crowded transportation, lack of basic services, low educational standards and unemployment (Lynch, 2005).

In order to sustain development, the supply and quality of major consumables and inputs to daily lives and economic production - such as air, water, energy, food, raw materials, land, and the natural environment needs to be taken care of. Land is essential because food and raw materials originate from it. Land provides habitat for flora and fauna. Thus, any disturbance to this resource by way of change in land use such as conversion of forestland or agricultural land into built-up area is irreversible. The use of land unsuitable for development may be unsustainable for the natural environment as well as to the humans. It is therefore essential that studies should be undertaken on the patterns of urban growth for better understanding of the trend so as to minimise the adverse consequences. Ile-Ife, a cultural city and an educational centre, has grown both in population and areal extent. With the continuous expansion, farmlands, wetlands and forests have been destroyed being turned in to built-up areas thus causing adverse effects to the environment. In order to ensure effective planning and environmental protection, an analysis of the past and present growth phenomena of the area is very important. Therefore, this study was carried out to map out the successive spatio-temporal urban change for better understanding and reliable growth projections. 


\section{Literature Review and Theoretical Framework}

Many scholars have made spirited efforts in urban growth modelling in both the developed and developing countries. Walsh et al. (1990), for instance, showed that thematic overlays contained within GIS could be used as reference sources for defining the spatial location of phenomenon and also for comparing such phenomenon against identified features employing digital processing of remote sensing images and selected thematic overlays. Gill et al. (1999) studied the uses of GIS analysis for city planners. They concluded that one of the biggest issues from any viewpoint is the availability of resources. However, this presents a challenge to full integration of GIS capabilities for planning purposes, especially in less developed countries. Pontius et al. (2000) used GIS techniques to predict the scenarios of land use change in the Ipswich watershed, USA over a period of two decades. Barnes et al. (2001) added that physical expressions and patterns of sprawl can be detected, mapped, and analysed using remote sensing and GIS technologies. The patterns of sprawl are being described using a variety of metrics, through visual interpretation techniques, all with the aid of software and other application programs.

In urban growth modelling studies, spatial phenomenon can be simulated geometrically using techniques of cellular automata (CA) such as adopted by Torrens and Sullivan (2001) and Waddell (2002). Barr et al. (2002) attempted a classification of land-cover characterisation using visual interpretation of higher resolution aerial photography. Epstein et al. (2002) bring out the techniques for mapping suburban sprawl by evaluating the traditional unsupervised classification and proposed GIS buffering approach for mapping the suburban sprawl with special reference to classification of the built-up area. Lo and Yang (2002) hinted that modelling of the spatial dynamics rests mostly with the land cover/land use change studies or urban growth studies. While Wang and Wester (2001) and Laurance et al. (2002) chose more extensive remotes sensing processing, using several steps and complicated transformations before beginning the GIS analysis, Heasley (2003) limited her use of remote sensing imagery to scanning in the photos to ARC/INFOR and creating her land cover classes that way.

Ifatimehim et al. (2007) remarked that the growth of urban centres could aggravate various population pressures, climatic variability and fragmentation of tenure and traditional system. According to them, the conversion of arable land to built-up environment to incorporate residential and industrial estates contribute to degradation of soil and vegetation, and worsening of food security in rural areas, mostly at the fringe of rapidly growing urban settlements. Remote sensing techniques gather data about earth's surface features in raster form on a periodic basis. Geographic Information System (GIS) helps in the analysis and integration of relational data base containing both spatial and non-spatial details through automated machine processing system provides and alternative means for the mapping of dynamic features on regular intervals. By such integrated study it is possible to take relevant decisions at the appropriate time by the urban planners (Shelton \& Estes, 1981). However, it should be noted that computer aided classification of satellite digital data sometimes have accuracy and reliability limitations in quality, thus making them unsuitable for certain management applications.

Various theories have been used to explain the spread of urban areas. The three major theories are: Concentric Growth Zone Hypothesis (Burgess, 1925) theorized that there are five concentric zones in a city, which were determined by the spatial competition. They include: Central Business District (CBD); the transition zone consisting of residential buildings with business and light manufacturing; working class zone where labourers in nearby factories reside; high income residential zone (residential districts); and the commuters zone which is the outlying suburban areas. Sector Theory (Hoyt, 1939) is a critique of the concentric hypothesis. Hoyt proposed that spatial competition is not the only source of the city's growth; other factors like prestigious location, social kinship and affinity also play important roles. Thus the cities grow in sectors rather than in concentric zones. Multiple nuclei theory was advanced by Harriss and Ullman (1945). It urges that there are distinctive districts where activities are concentrated. While the concentric zone hypothesis proposed that cities grow in zones from the centre outwards, the multiple nuclei theory proposes that these are not necessarily zones, but that similar activities are grouped together in certain districts. However, urban centres do not follow a particular growth theory. Therefore there is the need to identify the growth pattern and the resultant morphology of any urban system in order to assess impacts on the environmental and ecological settings and forecast the future trends of land use and land cover characteristics.

\section{The Study Area}

The study covered Ile-Ife and its environments made up of four Local Government Areas: Ife Central, Ife East and Ife North and Ife South. Two of these, Ife Central and Ife East, are located within Ile-Ife Township and contain a population of 501,952. Ile-Ife is an ancient town in currently Osun state, South-western Nigeria. In fact, it is the source of Yoruba tribe and the first settlement in South-western part of Nigeria. It is located between 
latitudes $7^{\circ} 28^{\prime} \mathrm{N}$ and $7^{\circ} 45^{\prime} \mathrm{N}$ and longitudes $4^{\circ} 30^{\prime} \mathrm{E}$ and $4^{\circ} 34^{\prime} \mathrm{E}$ (Figure 1). Ile-Ife is surrounded by rural settlements where agriculture is the chief occupation. However, Ile-Ife itself is a highly commercialized city that depends on the surrounding hinterland for most of its food supply. Ile-Ife has an undulating terrain underlain by metamorphic rocks and characterized by two types of soils, deep clay soils on the upper slopes and sandy soils on the lower parts (Smyth \& Montgomery, 1962).
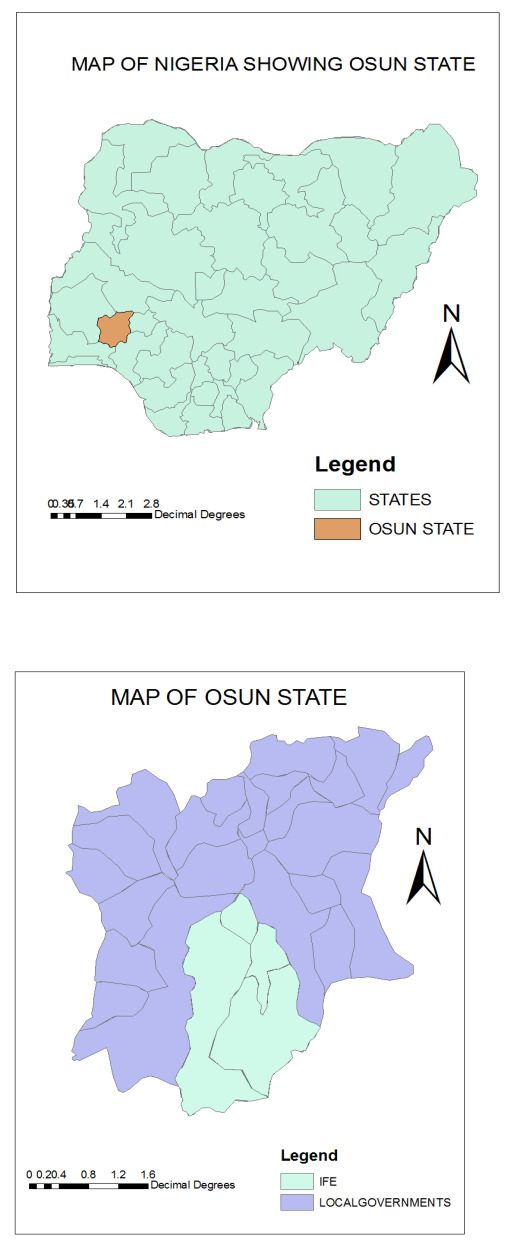

IFE SHOWING LOCAL GOVERNMENTS AND TOWNS

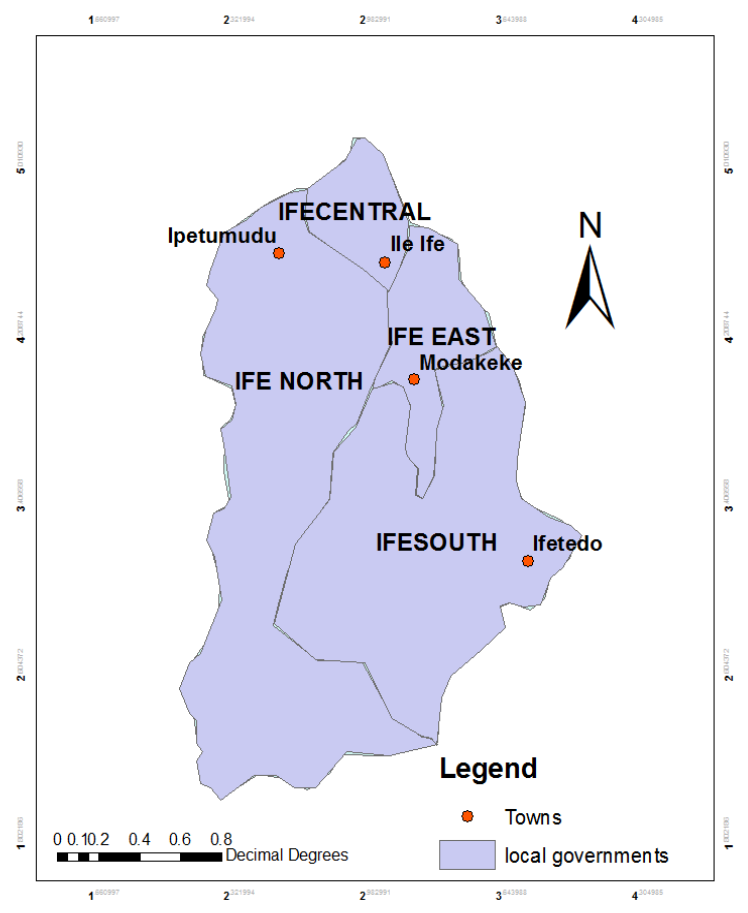

Figure 1. Location of Ile-Ife in Osun State, Nigeria

\section{Materials and Methods}

Both primary and secondary data which contain both spatial and non-spatial attributes were used in this study. Topographical Map of the study area (Sheet No. 322) on a scale 1:50,000; Multi-temporal Landsat Satellite Imageries (1986 to 2002); Alos Imagery (2007); and ground truthing constituted primary sources of data. Landsat TM and ETM scenes taken in November, December and January were selected because of their reflecting stability, and minimal spectral similarity. Secondary data were sourced from the Administrative Map of the area. The classified land-uses were segmented and converted to vector to create class statistics which was used to compute the rate and magnitude of change.

Three methods of data analysis were adopted in this study. First, the land use/land cover types for each study year were calculated. Overlay Operation was performed wherein the topographical map was converted to Tiff format and laid on the images to classify land-uses in the study area. Information obtained from the overlay was updated through ground truthing. Overlay operations was used to identify the actual location and magnitude of change. Third, Land Consumption Rate and Coefficient was calculated to determine the trend of change using Kappa coefficient. 


\section{Results and Discussion}

The main categories of land uses identified in the study area are: built-up area, natural vegetation, water body, rock outcrop and cultivated area (Table 1). The pixel statistics of land use in Landsat TM 1986 presented in Table 1 shows that the area covered by natural vegetation was $167.43 \mathrm{~km}^{2}$ representing $60.79 \%$ of the study area. Cultivated area accounted for $29.58 \%$ of the area. Whereas rock outcrop area covered $4.48 \mathrm{~km}^{2}$, that is, $1.7 \%$, water body occupied $4.39 \mathrm{~km}^{2}(1.6 \%)$ of the entire study area. The built-up area accounted for $6.40 \%\left(17.63 \mathrm{~km}^{2}\right)$ of the study area. These land use classes suggest that in 1986, much development had not taken place in the study area. The large cultivated area indicates that majority of the populace were farmers. In 2002 natural vegetation was still the dominant land cover class with $135.3 \mathrm{~km}^{2}$ covering approximately $49.06 \%$ of the study area though it has shared off about $11 \%$ of its original area extent. The pixel representing cultivated area constituted $26.38 \%$ of the entire study area in 2002 (Table 1); rock outcrop area accounted for $5.6 \mathrm{~km}^{2}(2.07 \%)$ water body remain fairly constant while on the contrary built-up area increased to $58.6 \mathrm{~km}^{2}(21.27 \%)$. Alos 2007 image showed that the built-up area increased to $79.40 \mathrm{~km}^{2}(28.82 \%)$ of the study area. Natural vegetation still retain dominant position with $199.80 \mathrm{~km}^{2}$ representing $43.48 \%$ coverage of the entire study area but have lost $47.64 \mathrm{~km}^{2}$ while water body, rock outcrop and cultivated area accounted for $3.21 \mathrm{~km}^{2}(1.17 \%), 4.7 \mathrm{~km}^{2}(1.71 \%)$ and $64.39 \mathrm{~km}^{2}(24.82 \%)$ respectively (Table 1$)$.

Table 1. Classification of land-uses (in $\mathrm{km}^{2}$ )

\begin{tabular}{lllllll}
\hline \multirow{2}{*}{ Land use/cover class } & \multicolumn{2}{c}{1986} & \multicolumn{2}{c}{2002} & \multicolumn{2}{c}{2007} \\
\cline { 2 - 7 } & Area $\left(\mathrm{in} \mathrm{km}^{2}\right)$ & $(\%)$ & Area $\left(\right.$ in $\left.\mathrm{km}^{2}\right)$ & $(\%)$ & Area $\left(\right.$ in $\left.\mathrm{km}^{2}\right)$ & $(\%)$ \\
\hline Built-up Area & 17.6373 & 6.40 & 58.6661 & 21.27 & 79.3959 & 28.82 \\
Water Body & 4.3978 & 1.60 & 3.3888 & 1.23 & 3.2199 & 1.17 \\
Rock Outcrop & 4.4829 & 1.63 & 5.6988 & 2.07 & 4.7107 & 1.71 \\
Natural Vegetation Area & 167.4302 & 60.79 & 135.3079 & 49.06 & 119.8074 & $43.4 \%$ \\
Cultivated Area & 81.4725 & 29.58 & 72.7479 & 26.38 & 68.3941 & $24.8 \%$ \\
Total & 275.4207 & 100.00 & 275.8095 & 100.00 & 275.528 & 100.0 \\
\hline
\end{tabular}

Sources: Multi-temporal Landsat Satellite Imageries (1986 and 2002); Alos Imagery (2007).

Table 2 and Figure 2 show the magnitude and frequently of changes between 1986 and 2002, natural vegetation, water body, and cultivated area recorded negative magnitudes of change of $-32.12,-1.01$, and -8.72 , respectively. The implication of the negative values of magnitude and annual frequency of change is that land-uses lose land to some other uses. For example, cultivated area with annual frequency of change of -0.55 between 1986 and 2002 indicated that cultivatable land lose about $0.5 . \mathrm{km}^{2}$ annually to other land uses, largely the built-up area. Built-up area and rock outcrop were the only land uses that recorded positive magnitudes and annual frequencies of change of 41.03 , and $1.22 \%$ and 2.56 and 0.08 , respectively. This implies that the built-up area is gaining an average of $2.566 \mathrm{~km}^{2}$ of land annually between 1986 and 2002 .

Table 2. Changes in land use of Ife between 1986 and 2002

\begin{tabular}{llllll}
\hline Land use/cover Class & $\begin{array}{l}1986 \\
\left(\mathrm{~km}^{2}\right)\end{array}$ & $\begin{array}{l}2002 \\
\left(\mathrm{~km}^{2}\right)\end{array}$ & $\begin{array}{l}\text { Magnitude of change } \\
\left(\mathrm{km}^{2}\right)\end{array}$ & $\begin{array}{l}\text { Frequency of change } \\
\left(\mathrm{km}^{2}\right)\end{array}$ & Percentage change \\
\hline Built-up Area & 17.6373 & 58.6661 & 41.03 & 2.56 & 232.63 \\
Water Body & 4.3978 & 3.3888 & -1.01 & -0.063 & -22.97 \\
Rock Outcrop & 4.4829 & 5.6988 & 1.22 & 0.08 & 27.21 \\
Natural Vegetation Area & 167.4302 & 135.3079 & -32.12 & -2.01 & -19.18 \\
Cultivated Area & 81.4725 & 72.7479 & -8.72 & -0.55 & -10.7 \\
Total & 275.4207 & 275.8095 & & & \\
\hline
\end{tabular}

Sources: Multi-temporal Landsat Satellite Imageries (1986 and 2002). 


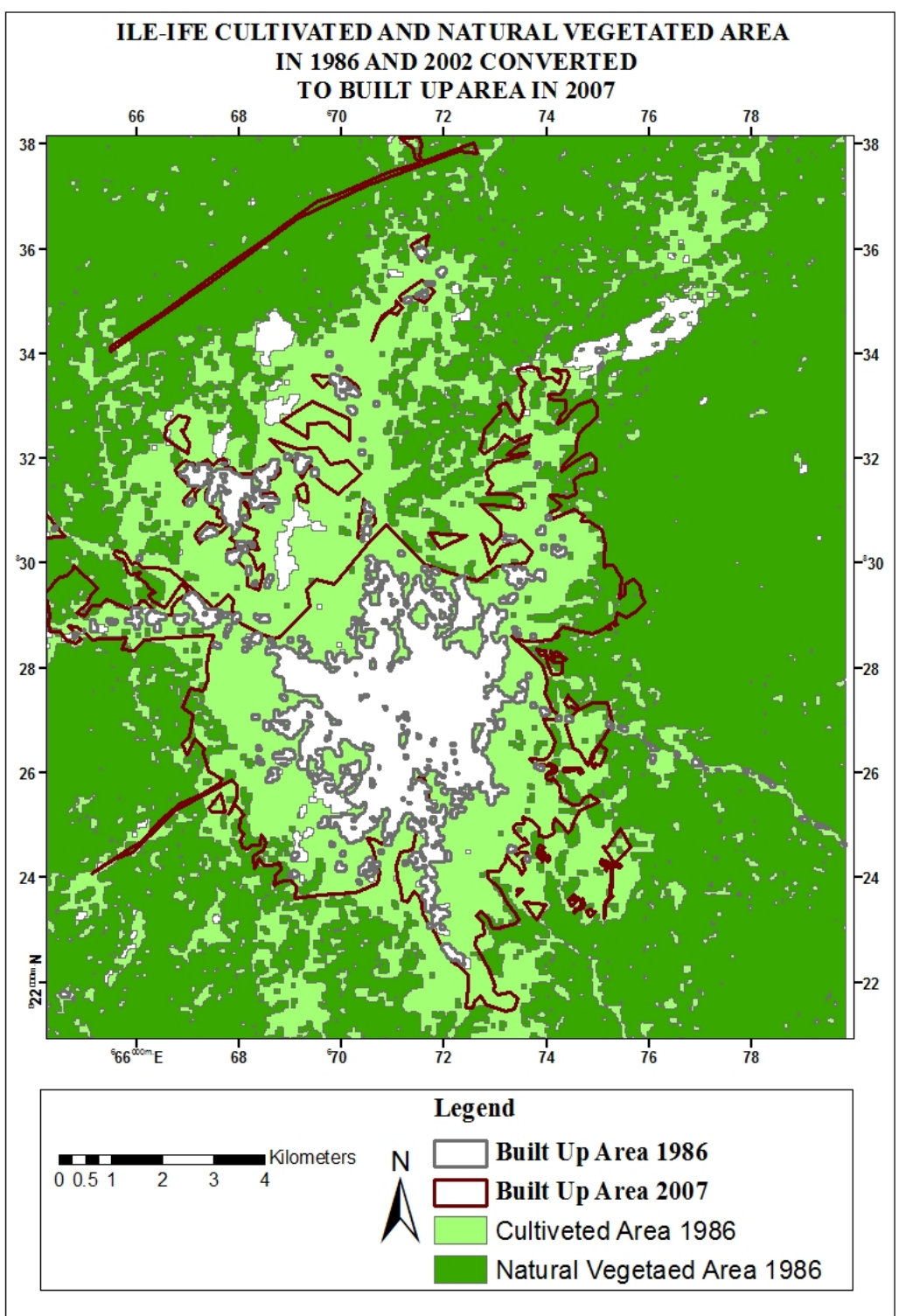

Figure 2. Cultivated Land and Natural Vegetated Areas Converted to Built-up between 1986 and 2007

Between 1986 and 2007, natural vegetation, water body, rock outcrop, and cultivated area recorded negative magnitude and annual frequency of change (Table 3).

Table 3. Changes in land use of Ife between 1986 and 2007

\begin{tabular}{lllllll}
\hline Land use/cover Class & $\begin{array}{l}1986 \\
\left(\mathrm{~km}^{2}\right)\end{array}$ & $\begin{array}{l}2007 \\
\left(\mathrm{~km}^{2}\right)\end{array}$ & $\begin{array}{l}\text { Magnitude of Change } \\
\left(\mathrm{km}^{2}\right)\end{array}$ & $\begin{array}{l}\text { Frequency of Change } \\
\left(\mathrm{km}^{2}\right)\end{array}$ & $\begin{array}{l}\text { Percentage } \\
\text { Change }\end{array}$ \\
\hline Built-up Area & 17.6373 & 79.3959 & 61.76 & 2.94 & 350.17 \\
Water Body & 4.3978 & 3.2199 & -1.18 & -0.06 & -26.83 \\
Rock Outcrop & 4.4829 & 4.7107 & 0.23 & 0.01 & 5.13 \\
Natural Vegetation Area & 167.4302 & 119.8074 & -47.62 & -2.27 & -28.44 \\
Cultivated Area & 81.4725 & 68.3941 & -13.08 & -0.62 & -16.05 \\
Total & 275.4207 & 275.528 & & &
\end{tabular}

Sources: Multi-temporal Landsat Satellite Imageries (1986); Alos Imagery (2007). 
On the whole, within twenty-one years, the built-up area increased from $17.6 \mathrm{~km}^{2}$ to $79.39 \mathrm{~km}^{2}$ with $350.11 \%$ of change implying that the built-up area had multiplied approximately three and half times between 1986 and 2007 , while cultivated land losses approximately $17 \%$ of its total land extent. The trend of urban growth from 1986 to 2007 indicated that cultivated and natural vegetated area converted to built-up area. Figure 3 shows the comparative loss and gain of each land class between 1986 and 2007. Using overlay of the multi-date classified imageries, the changes are well visualized (Figure 4).
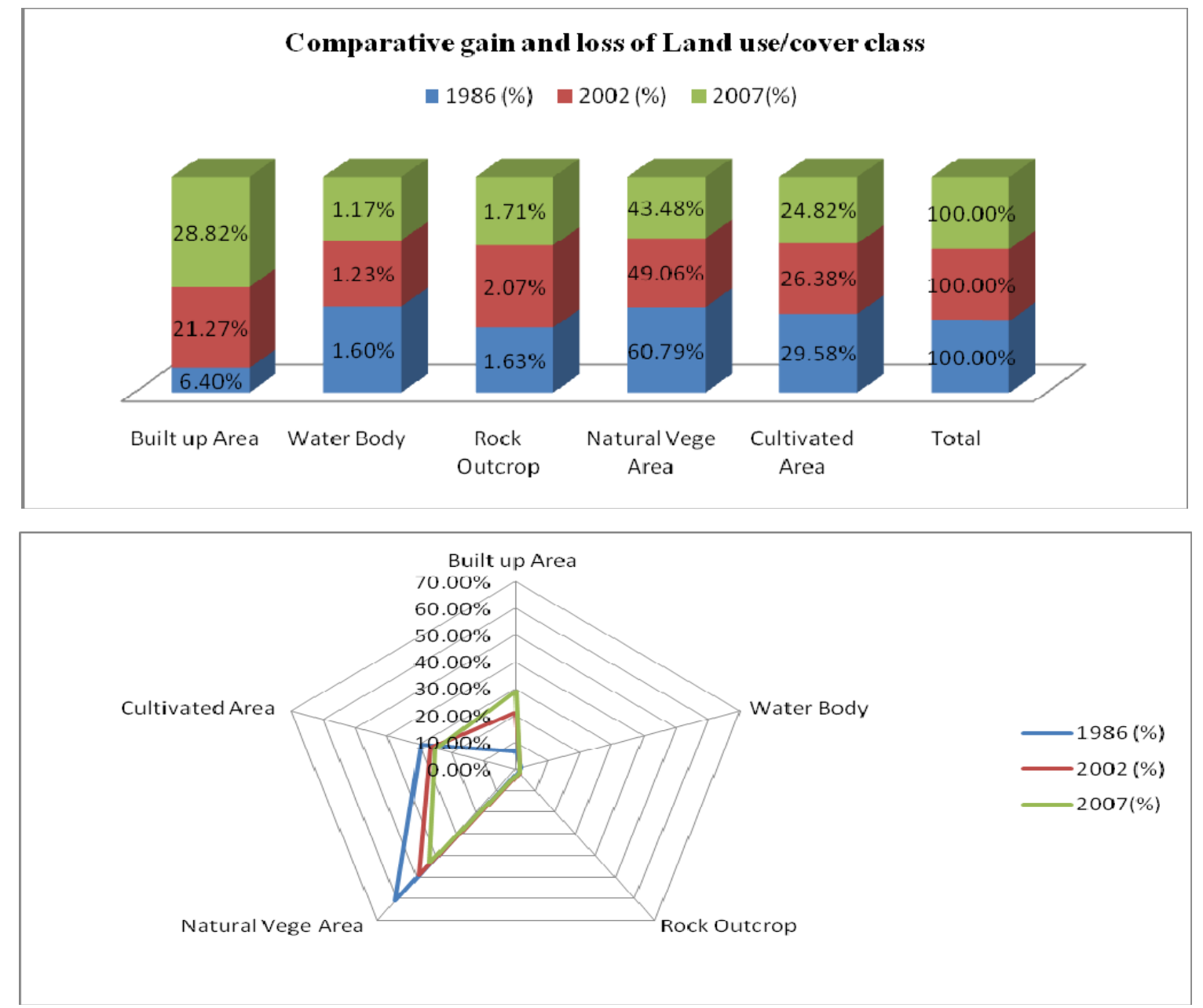

Figure 3. Comparative gain and loss of land use/land cover class 


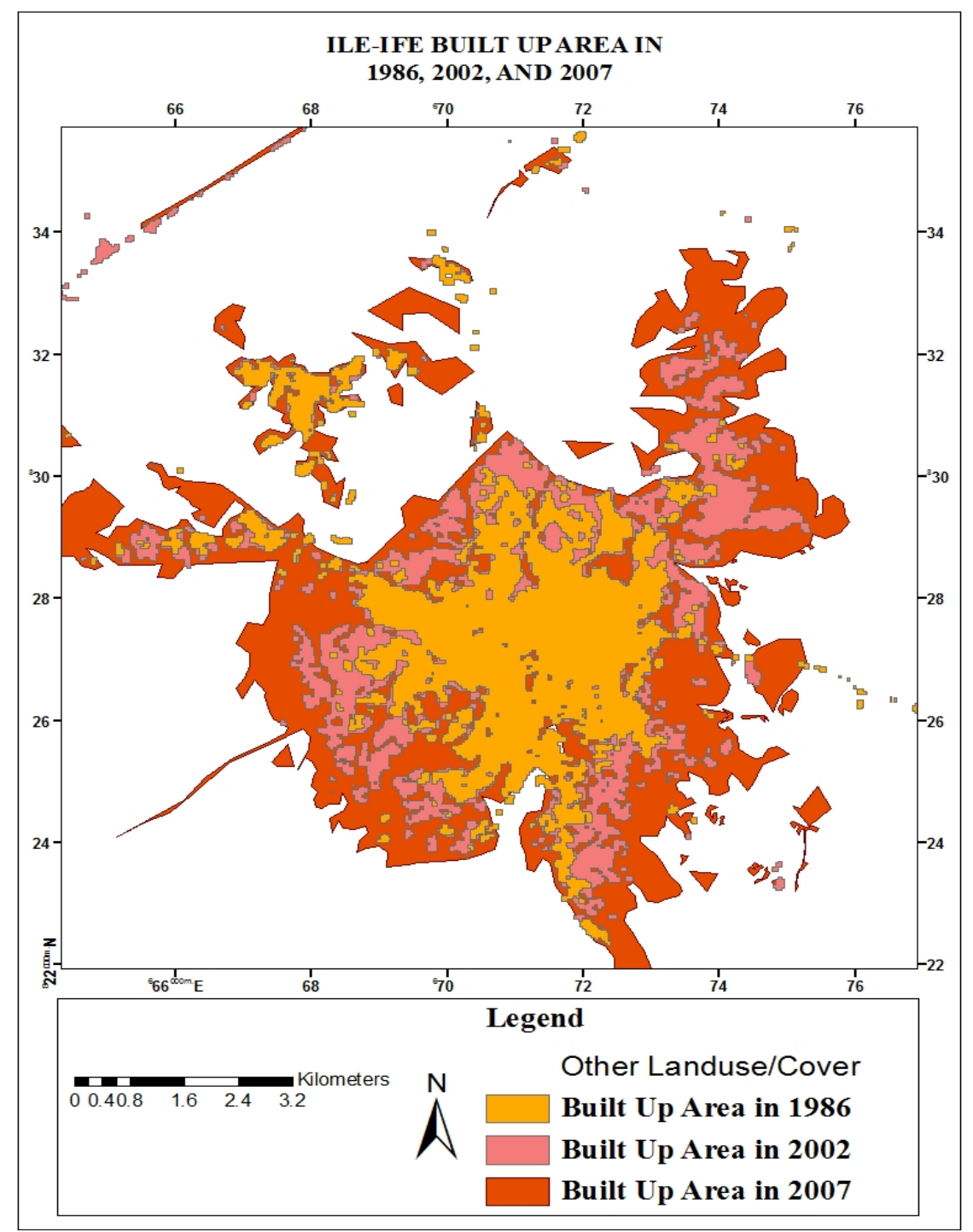

Figure 4. Overlay of 1986, 2002 and 2007 indicating changes in the extent of the built-up areas

Several interrelated factors are responsible for urban growth and land use changes in the study area. These factors include population growth, political/historical function and socio-economic activities. Population growth, historical factor and the function of Ile-Ife as an education town were the major drive of land use changes in the study area. Formally Ile-Ife was known for farming and cultural headquarter for most Yoruba people but with the establishment of a University in the 1960s other activities were also introduced which attracted people from all corners of the state and beyond; this stimulated the need for land for buildings, road, and other socio-economic needs. Cultivated land was favourable due to its proximity, suitability and readily availability for building unlike the wet land and natural vegetated area that will cost more to sand fill or clear. This contributed to the high decrease of cultivated land in relation to other land use. In addition some cultivated lands were left to fallow and abandoned due to rural-urban migration. The wet land area and patches of water bodies as well as increase in road network have greatly modified the morphology of the built-up area which is more of web-like radial-pattern.

\subsection{Urban Growth}

Built-up area is commonly used to determine the growth and urbanization of cities. The increase in built-up area over the period covered by the study indicated the spatial extent of urban growth of Ile-Ife. 


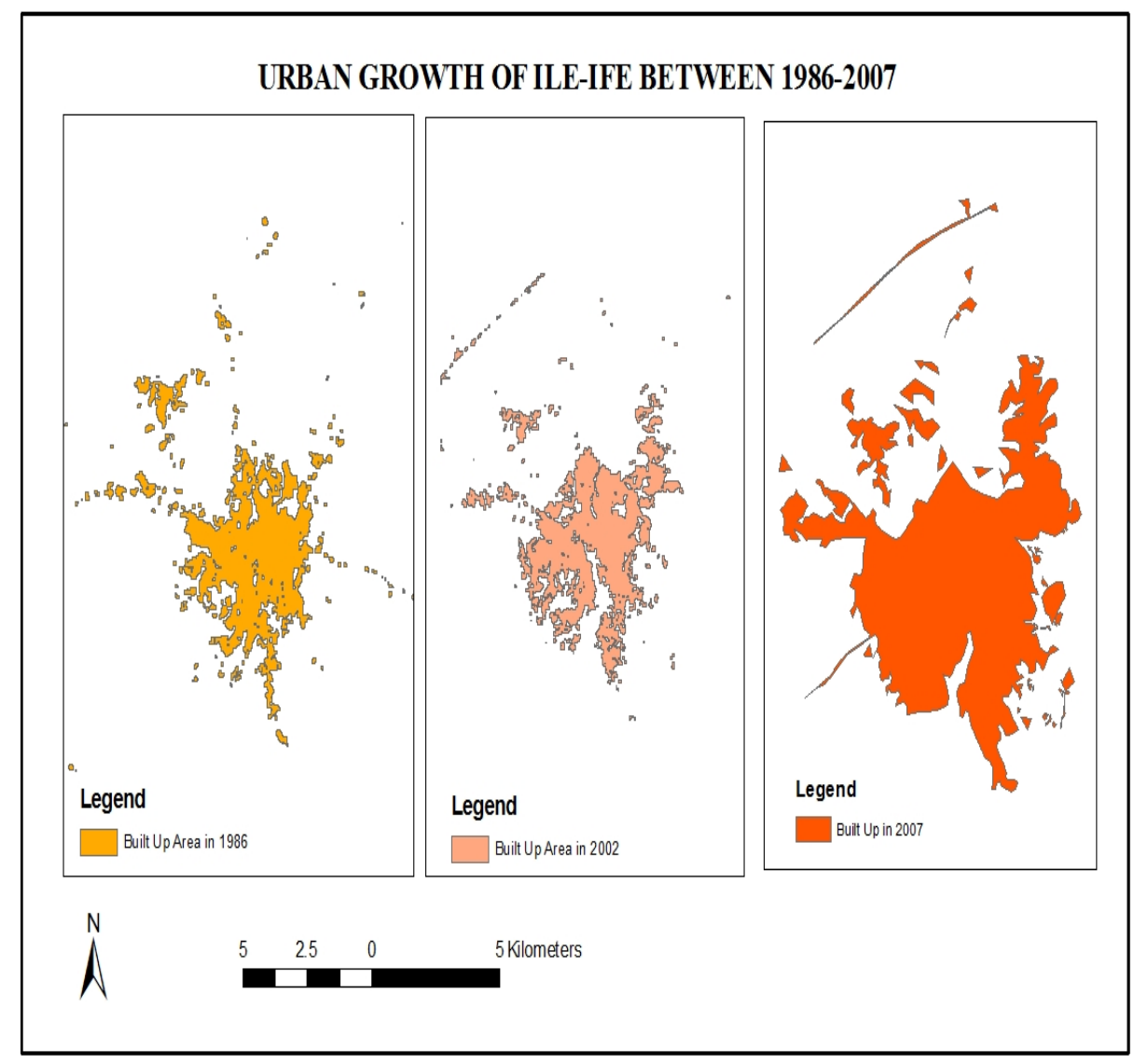

Figure 5. Urban growth of Ife 1986, 2002 and 2007

\subsection{Land Consumption Rate and Coefficient}

Table 5 show the population density of the study area in respect to built-up area for the different year understudy. 1986 recorded a population density of 9095 per km$^{2}$ while the value increased to 4339 per km ${ }^{2}$ in 2002 and 6674 in 2007. This indicated increase in population and increase in the use of land. This is further supported with the increase in land consumption and land consumption coefficient (Table 5 and Figure 5).

Table 4. Population evolution of Ile-Ife between 1986 and 2007

\begin{tabular}{llll}
\hline \multicolumn{1}{c}{ Year } & Population & Population Growth & Annual Growth Rate \\
\hline $1986^{*}$ & 160,415 & ---------- & ---------- \\
$2002 * *$ & 254,685 & $58.76 \%$ & $3.67 \%$ \\
$2007 * *$ & 529,905 & $108 \%$ & $21.6 \%$ \\
\hline
\end{tabular}

Sources: *Ife Central Local Government Projection based on 1963 National Census Figures

** Osun State Government Projection based on 1991 National Census Figures

***Authors' Projection based on 2006 National Census Figures 
Table 5. Population density of the study area using the built-up area

\begin{tabular}{llllll}
\hline Year & Population & $\begin{array}{l}\text { Built-up } \\
\text { Area }\left(\mathrm{km}^{2}\right)\end{array}$ & $\begin{array}{l}\text { Population } \\
\text { Density }\left(\text { per km }{ }^{2}\right)\end{array}$ & Land Consumption Rate & Land Consumption Coefficient \\
\hline 1986 & 160,415 & 17.6373 & 9095 & 0.109 & $1986-2002=0.00044$ \\
2002 & 254,685 & 58.70 & 4339 & 0.230 & $2002-2007=0.000075$ \\
2007 & 529,905 & 79.40 & 6674 & 0.149 & \\
\hline
\end{tabular}

Source: Computed from Tables 1 to 4.

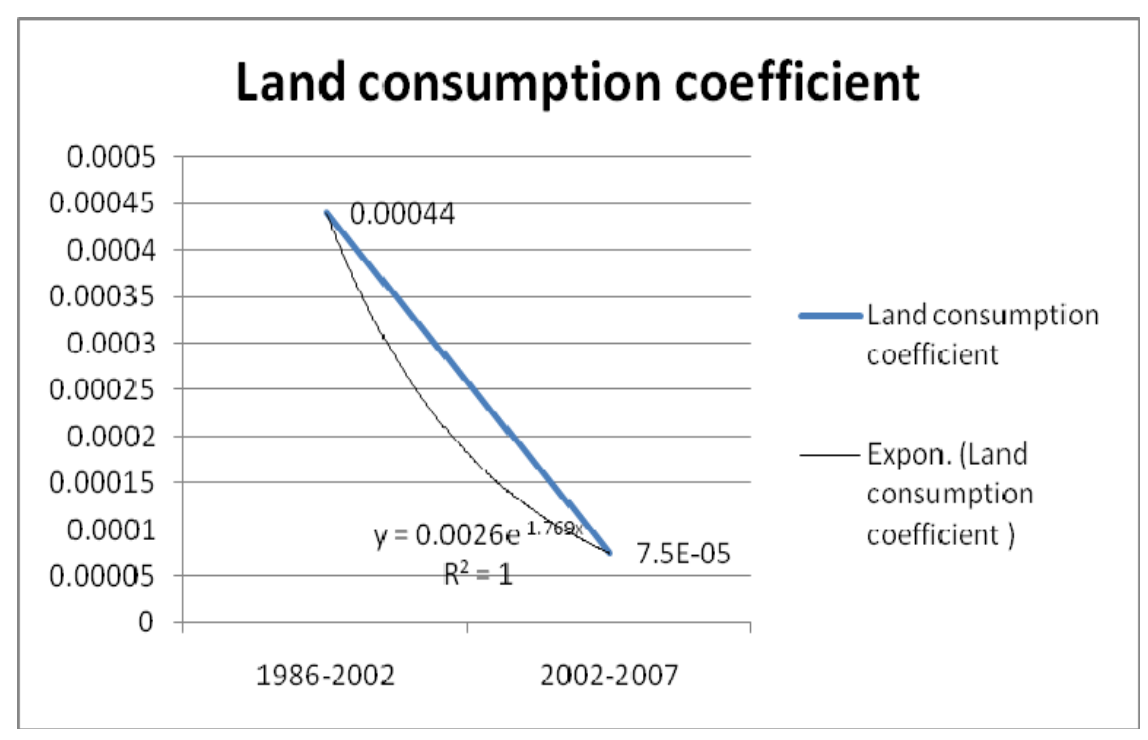

Figure 6. Land Consumption Coefficient

Using the Land Consumption Coefficient indices of the annual frequency at $2.95 \mathrm{Km}^{2}$ and percentage of change of $350 \%$, the built-up area of Ile-ife which at present is about $88 \mathrm{Km}^{2}$ will increase to about $130 \mathrm{Km}^{2}$ by the year 2022 (Figures 7 and 8) while the other land ues land cover class will continue to decrease. This expected incerase in the built-up area is demostrated in Figure 7.

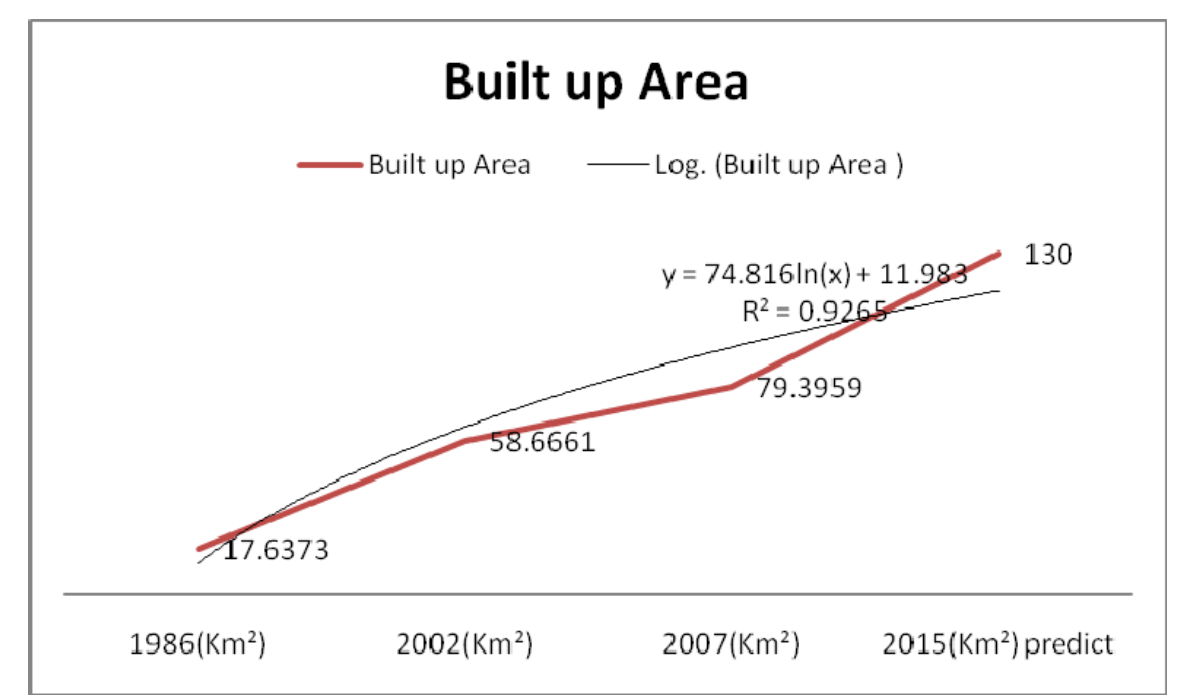

Figure 7. Predicted Built-up Area of Ile-Ife by 2022 


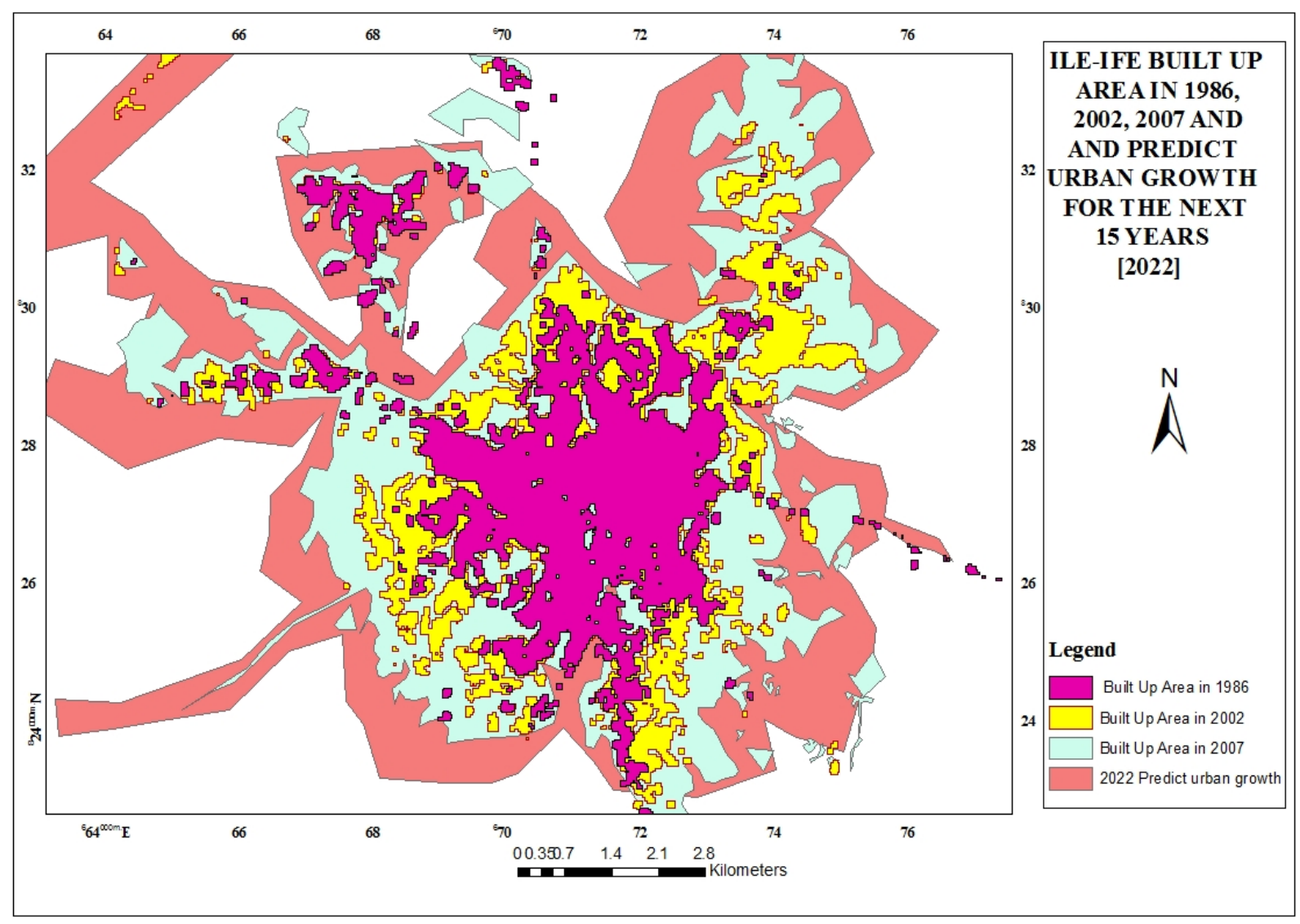

Figure 8. The built-up area of Ile-Ife and predicted urban growth by 2022

\section{Summary of Findings}

The study, through the use of remote sensing techniques and data, has revealed the spatial dynamics of Ile-Ife main town and its environments between 1986 and 2007. The study was carried out with the aid of Landsat TM of 1986 and Landsat ETM + of 2002 and Alos 2007. The study has revealed that change is constant and inevitable. Ile-Ife has been changing in all forms of land-uses /land cover. Asides the built-up area, all other land-uses/ land covers including natural vegetation, water body, wetland area and cultivated area recorded negative magnitudes, annual frequencies and percentages of changes. This showed that, only the built-up area was gaining in area extent while all other land-uses/land cover classes are losing in area covered.

The study also showed the pattern and morphology of the study area to be a web-like radial pattern. The major factors driving the dynamics of the study area in respect of the spatial structure and areal extent are such factors as increase in population, creation of more Local Government Areas within the study area, and demand for more social-economic services. Land consumtion rate/coefficent was foud to be $2.95 \mathrm{~km}^{2}$ while the annual frequency and percentage of change was $350 \%$. At this rate, it was predicted that the built-up area of Ile-Ife which at present is about $88 \mathrm{Km}^{2}$ will increase to about $130 \mathrm{~km}^{2}$ by 2022 .

\section{Conclusion}

This study has demonstrated the use of remote sensing techniques and related data, multi-date satellite imageries in characterizing land use/ land cover and urban dynamics by exemplifying Ile-Ife in Osun State of Nigeria. The study showed that there were periodic changes in the growth extent and structure of the study area. The built-up area was found to be expanding at the expense of the remaining land use types.

The study has also demonstrated the capability of remote sensing and GIS technologies for mapping and detecting changes in Land use/land cover and urban growth. In addition, it has demonstrated that these modern technologies with field observation can provide useful tools in showing both land cover conversion and modification. The prediction made in the study suggests that the built-up area will keep increasing at the expense of other Land use/land cover classes if regulation and proper planning is not put in place. 


\section{Implications of the Study}

With development and demand for more infrastructural services, the impacts of urban sprawl would be on the natural resources and ecology. Thus, it is required that urban growth is planned without hampering the natural resources and disturbing the rural set-up. Planning should also focus on a dispersed economic structure and aim at creation of balanced ecological, social, and economic systems.

Ile-Ife is growing at a fast rate, it therefore implies that adequate land use planning controls should be adopted in order to mitigate and control the growth pattern and rate. In addition, town planners and other policy makers in charge of urban area should be empowered with Remote Sensing/GIS training in order to improve their skills in managing the environment. The $0.62 \mathrm{~km}^{2}$ of the cultivated land lost to the built-up area annually imply that food production is threatened and employment of labour through agriculture will suffer greatly in the nearest future. In addition, the $2.27 \mathrm{~km}^{2}$ loss of natural vegetation is capable of aiding increase of surface temperature thereby resulting in a change or at least a large variation in climatic characteristics of the area.

In view of the implications of this study it is opined that the inhabitants of Ile-Ife and its environments should be educated on the need for environmental protection to avoid indiscriminate cutting down of tress and removal of land cover. Tree planting should be encouraged as a step to reclaim the lost vegetation cover of the study area and to solve problems associated with climate change such as erosion of top soils, temperature regulation, water table maintenance and air pollution control through sequestration of carbon dioxide which is a major green house gas. In addition, polices should be put in place to protect any cultivatable land, while farming should be made attractive to reduce rural-urban migration.

\section{References}

Barnes, K. B., Morgan, J. M., Roberge, M. C., \& Lowe, S. (2001). Sprawl Development: its Patterns, Consequences and Measurement. Towson University. Retrieved from http://chesapeake.towson.edu/landscape/urbansprawl/

Batty et al. (2003). Traffic, Urban Growth and suburban Sprawl. Centre for Advanced Spatial Analysis (p. 6). London, U. K.: University College.

Burgess, P. (1998). Revisiting Sprawl: Lessons from the Past. The Urban Center Publications. Cleveland, OH: Cleveland State University.

Cheng, J., Masser, I., \& Ottens, H. (2000). Understanding Urban Growth System: Theories and Methods. Geo Information, 3(3), 209-223.

Civco, D. L., Hurd, J. D., Wilson, E. H., Arnold, C. L., \& Prisloe, M. (2002). Quantifying and describing Urbanising Landscapes in the Northeast United States. Photogrammetric Engineering and Remote Sensing, 68(10), 1083-1090.

Cohen, B. (2003). Urban growth in developing countries: A Review of Current Trend and a Caution Regarding Existing Forecasts. World Development, 32(1), 23-51. http://dx.doi.org/10.1016/j.worlddev.2003.04.008

Epstein, J., Payne, K., \& Kramer, E. (2002). Techniques for Mapping Suburban Sprawl. Photogrammetric Engineering and Remote Sensing, 63(9), 913-918.

Fasal, S. (2000). Urban expansion and loss of agricultural land - A GIS based study of Saharanpur city, India. Environment and urbanisation, 12(2), 133-149. http://dx.doi.org/10.1177/095624780001200211

Harris, C., \& Ullman, E. I. (1945). The Nature of Cities. Annals of the American Academy of Political and Social Sciences, 242, 13. http://dx.doi.org/10.1177/000271624524200103

Herold, M., Goldstein, N. C., \& Clarke, K. C. (2003). The Spatiotemporal Form of Urban Growth: Measurement, Analysis and Modeling. Remote Sensing Environment, 86, 286-302. http://dx.doi.org/10.1016/S0034-4257(03)00075-0

Hurd, J. (2001). Characterization of Forest Fragmentation and Urban Sprawl Using Time Sequential Landsat Imagery. Proceedings of ASPRS Annual Convention, St. Louis

Ifatemehin, O. O., \& Ufuah, M. E. (2007). An Analysis of Urban Expansion and Loss of Vegetation Cover in Lokoja, using GIS Techniques. Zaria Geographers, 16(2).

Lata, K. M., Sankar, R. C. H., Krishna, P. V., Badrinath, K. V. S., \& Raghavaswamy. (2001). Measuring urban sprawl: A Case Study of Hyderabad. GIS Development, 5(12).

Lynch, K. (2005). Rural Urban Interaction in the Developing World. Routledge: Taylor and Francis Group. 
Maconachire, R. (2002). Urban Growth and Land Degradation in Developing Cities. Ashgate Publishing limited.

Osun State Government of Nigeria. (2002) Osun State Statistical Year Book. Osogbo: Government Press.

Pathan, S. K. Shukla, V. K., Patel, R. G., Patel, B. R., \& Mehta, K. S. (1991). Urban Land Use Mapping - A Case Study of Ahmedabad, Photonirvachik. Journal of Indian Society of Remote Sensing, 19(2), 95-112. http://dx.doi.org/10.1007/BF03008125

Pontius, R. G. (2002). Statistical Methods to Partition Effects of Quantity and Location During Comparison of Categorical Maps at Multiple Resolutions. Photogrammetric Engineering \& Remote Sensing, 68(10), 1041-1049.

Robinove, C. J. (1981). The Logic of Multispectral Classification and Mapping of Land. Remote Sensing of Environment, 11, 231-244. http://dx.doi.org/10.1016/0034-4257(81)90022-5

Salau, A. T. (1992). Urbanisation and Spatial Strategies in West Africa. In R. B. Potter, \& A. T. Salau (Eds.), Cities and Development in the Third World (pp. 157-171). London: Mansell Publishing Ltd.

Shelton, \& Estes, J. E. (1981). Remote Sensing and Geographic Information System - an Unrealised Potential. Geo-Processing, 385-420.

Theobald, D. M. (2001). Quantifying Urban and Rural Sprawl Using the Sprawl Index. Paper presented at the Annual Conference of the Association of American Geographers, New York, March 2nd.

Torrens, P. M., \& Alberti, M. (2000). Measuring sprawl. Working Paper No. 27, London: Centre for Advanced Spatial Analysis, University College London. Retrieved from http://www.casa.ac.uk/working_papers/

United Nations Centre for Human Settlements - Habitat. (1996). An Urbanizing World: Global report on Human Settlements (pp. 93-131). Oxford: Oxford University Press.

Yeh, A. G. O., \& Xia, L. (2001). Measurement and Monitoring of Urban Sprawl in a Rapidly Growing Region Using Entropy. Photogrammetric Engineering and Remote Sensing, 67(1), 83. 